\title{
Advances and Promises of Epigenetics for Forest Trees
}

\author{
Joana Amaral ${ }^{1,+}{ }^{\oplus}$, Zoé Ribeyre ${ }^{2,+}$, Julien Vigneaud ${ }^{3,+}$, Mamadou Dia Sow ${ }^{3, \ddagger}$, Régis Fichot ${ }^{3}$, \\ Christian Messier ${ }^{2,4}$, Gloria Pinto ${ }^{1}$, Philippe Nolet ${ }^{2}$ (D) and Stéphane Maury ${ }^{3, *(D)}$ \\ 1 CESAM - Centre for Environmental and Marine Studies, Department of Biology, University of Aveiro, \\ 3810-193 Aveiro, Portugal; jsamaral@ua.pt (J.A.); gpinto@ua.pt (G.P.) \\ 2 Département des Sciences Naturelles, Institut des Sciences de la Forêt Tempérée (ISFORT), Centre d'étude de \\ la Forêt (CEF), University of Québec en Outaouais (UQO), Ripon, QC J0V 1V0, Canada; ribz01@uqo.ca (Z.R.); \\ christian.messier@uqo.ca (C.M.); philippe.nolet@uqo.ca (P.N.) \\ 3 Laboratoire de Biologie des Ligneux et des Grandes Cultures (LBLGC), INRAe, University of Orléans, \\ EA 1207 USC 1328, 45067 Orléans, France; julien.vigneaud@etu.univ-orleans.fr (J.V.); \\ mamadou-dia.sow@inrae.fr (M.D.S.); regis.fichot@univ-orleans.fr (R.F.) \\ 4 Département des Sciences Biologiques, Centre d'Étude de la Forêt (CEF), University of Québec à \\ Montréal (UQAM), Montréal, QC H2L 2C4, Canada \\ * Correspondence: stephane.maury@univ-orleans.fr; Tel.: +33-2-38-41-70-22 \\ + These authors contributed equally. \\ $\ddagger$ Present address: GDEC INRAe, 5 chemin de Beaulieu, 63000 Clermont-Ferrand, France.
}

Received: 30 June 2020; Accepted: 7 September 2020; Published: 10 September 2020

\begin{abstract}
The importance of tree genetic variability in the ability of forests to respond and adapt to environmental changes is crucial in forest management and conservation. Along with genetics, recent advances have highlighted "epigenetics" as an emerging and promising field of research for the understanding of tree phenotypic plasticity and adaptive responses. In this paper, we review recent advances in this emerging field and their potential applications for tree researchers and breeders, as well as for forest managers. First, we present the basics of epigenetics in plants before discussing its potential for trees. We then propose a bibliometric and overview of the literature on epigenetics in trees, including recent advances on tree priming. Lastly, we outline the promises of epigenetics for forest research and management, along with current gaps and future challenges. Research in epigenetics could use highly diverse paths to help forests adapt to global change by eliciting different innovative silvicultural approaches for natural- and artificial-based forest management.
\end{abstract}

Keywords: adaptation; breeding; climate change; DNA methylation; epigenomics; memory; priming; stress; trees

\section{Forests and Epigenetics in a Time of Global Change}

Forests represent a prime resource covering around $30 \%$ of the world's land surface, or 4 billion hectares [1]. These are dynamic ecosystems with a variety of functions that provide numerous social, economic, and environmental benefits. Forest productivity and health are currently threatened by global change, especially due to increasing drought and/or episodes of high temperature, as well as invasive insects and pests [2-5]. As the effects caused by abiotic and biotic stresses can last for long periods, there is a high probability of interaction with other stresses or disturbances to produce more stressful combined events [6-8]. The United Nations (https://www.un.org/esa/forests/wp-content/ uploads/2016/12/UNSPF_AdvUnedited.pdf) and the European Forest-Based Sector (https://www. forestplatform.org/wp-content/uploads/2020/05/SIRA_2030.pdf) recognize the need for a collaborative global response to achieve more adapted and resilient forests under a climate change scenario, such as the initiative from the International Union Of Forest Research Organizations (https://www.iufro.org/ fileadmin/material/publications/spotlights/spotlight75-iufro-task-forces.pdf). 
Forest trees are sessile, perennial, and modular organisms with complex life cycles that are often challenged by environmental variations during their long-lifespan. Surviving tree populations can respond to these environmental changes through complex and interacting mechanisms $[9,10]$ : Migration, adaptation, and phenotypic plasticity. At the individual scale, organisms can acclimate through phenotypic plasticity, i.e., the ability to produce different phenotypes in response to different environments [11]. Such plasticity is particularly important for non-mobile organisms, such as trees. Across generations, populations can shift their distribution (i.e., migrate) to remain at equilibrium with the climate [12], or they can remain in their present geographic location by improving their fitness and adapting to new climate conditions [13-16]. Such local adaptation is crucial for many tree species that will not be able to keep pace with climate change, such as sugar maple in North America [17]. The real challenge for ecologists, conservation biologists, and forest managers is to predict which of these two options, favor migration or adaptation, will be best for tree species $[18,19]$. The role of forest genetic material in responding to environmental changes is a key player in forest management and conservation [20]. As many species are unlikely to migrate fast enough to keep up with the rapidly changing climate, breeding programs should be rethought to incorporate climate change-related traits, including plasticity and adaptation, as selection criteria when exploring the high genetic variation in forest trees. Information from trials established to focus on growth/productivity traits should now be reinterpreted from the perspective of these new large-scale environmental challenges $[21,22]$ and new trials should be established addressing these explicit responses.

Functional traits are morphological, physiological, and phenological attributes that determine an organism's performance to a given environmental filter by impacting growth, reproduction, and survival $[18,23]$. It is crucial to identify relevant traits and thresholds for both a better selection of genetic material and species combinations to maximize sustainable ecosystem functions and resilience to climate change. Special attention should be given to traits not often previously considered in breeding depending on bioclimatic zones but likely to be fostered in the context of global change: Pest and disease resistance, drought resistance, fire resistance/tolerance, flood resistance, cyclone resistance, or salt tolerance $[5,20]$.

However, resistance and/or tolerance to stress are often difficult to measure and depend on a complex network of functional traits at multiple scales. For instance, 'drought resistance' can rely on diverse processes from those promoting growth maintenance under moderate water deficit to those promoting survival and recovery under severe and/or long-lasting water deficit $[24,25]$. These include traits related to the control of water loss [26,27], the maintenance of cell turgor [28-30], shifts in sink-source relationships and adjustments between transpiring vs. conducting or absorbing surface areas [31-33], or the maintenance of xylem hydraulic continuity [24,34]. Another example, 'insect defoliation resistance', is influenced by leaf strength, palatability, and phenolic content $[35,36]$. Hence, a holistic view of trees' adaptation to stress and the identification of sets of key functional traits are imperative.

Due to their wide ecological distributions and long-lifespans, trees have evolved numerous adaptations. Considerable effort has been paid to understanding the genetic basis of the traits underlying adaptive responses [37]. In the context of global change, such information will be especially useful for breeding, conservation, and resilient forest-based industry. Recent advances have, however, highlighted "epigenetics" as an emerging and promising field of research, along with genetics, for the understanding of tree phenotypic plasticity and adaptive responses [38-41]. Here, we argue that trees as long living organisms may particularly use epigenetics to facilitate phenotypic modifications in response to environmental changes. Research in epigenetics could use highly diverse paths to help forests adapt to global change by eliciting different innovative silvicultural approaches for naturaland artificial-based forest management. In this paper, we review recent advances in this emerging field and their potential for tree researchers and breeders, as well as the whole forest management community. We begin by presenting the basics of epigenetics in plants before discussing its potential for trees. We propose a bibliometric and overview of the literature on epigenetics in trees, including 
recent advances on tree priming, an adaptive strategy that improves their defensive capacity and resulting from a prior experience [42]. Finally, we outline the promise of epigenetics for forest research and management, along with current gaps and future challenges.

\section{Epigenetics in Plants: The Basics}

Epigenetics has been initially defined as "the branch of biology which studies the causal interactions between genes and their products, which bring the phenotype into being" [43]. The author also proposed the existence of a conceptual picture of this new discipline with the "epigenetic landscape", which represents the interactions between the environment and the genes leading to the development of a certain phenotype [44,45]. Here, we define it as the study of all the processes affecting the expression of genes and/or the activity of transposable elements (TEs) without altering the DNA sequence that may be heritable by mitosis (during development) and/or meiosis (across generations) [46-48] (Figure 1). Epigenetics has been proposed as being the missing part of heritability since the information encoded into the DNA nucleotide sequence by itself is often insufficient to explain biological variation in all of its complexity $[49,50]$. Accordingly, epigenomic studies chart the locations and understand the functions of all chemical tags that mark the genome (named epigenome). Epigenomics has quickly become a big data science, posing tremendous challenges of its translation into knowledge [51].

The main molecular support for epigenetic mechanisms in eukaryotes is chromatin structure (compaction and 3D positioning in the nucleus). Chromatin is formed through the association of DNA wrapped around nucleosomes (histones octamer). Its compaction is characterized either by a decondensed state (open chromatin or euchromatin) enriched in genes and permissive to transcription, or by a condensed state (closed chromatin or heterochromatin) enriched in repetitive sequences and silenced sequences. These states are controlled by marks defining chromatin domains [52,53] and allowing chromatin remodeler activity. The latter are protein complexes modifying the chromatin structure that then allow or prevent the transcription of genes to their destinations on the DNA [54,55]. The chromatin marks or "epigenetic marks" (when transmitted by cell division) are mainly DNA methylation, non-coding RNAs (ncRNAs), and histone modifications and variants [56-61]. Indeed, the incorporation of histone variants into nucleosomes and the addition of post-translational modifications to histones can alter the properties of nucleosomes and chromatin. The major histones are deposited during DNA replication, and all eukaryotes have variant types of $\mathrm{H} 2 \mathrm{~A}$ and $\mathrm{H} 3$, such as H2A.Z and H3.3 that are also incorporated into chromatin. In addition, histone proteins have shown that they can be extensively modified post-translationally at their N-terminal tails through the addition of acetyl, methyl, phosphoryl, and ADP-ribose groups, as well as peptides, such as SUMO and ubiquitin. The key players associated with these modifications are: (a) Writers-enzymes that modify the nucleotide bases and specific amino acid residues on histones, (b) erasers-enzymes that remove these marks, and (c) readers-proteins with specific domains that bind or interact with specific epigenetic marks of a locus (e.g., transcription factors) [62,63]. Epigenetic marks and their machinery may change in response to environmental variations occurring throughout the life cycle of an organism, and in some cases, may be inherited in the progeny (Figure 1).

DNA methylation is the most studied epigenetic mark because of its occurrence in both plants and mammals [64], its stability (mitosis and/or meiosis), its role in gene regulation $[60,62,65,66]$, in the silencing of TEs $[60,67,68]$, or in chromosome interaction $[60,69]$, and its facility to be studied at the genome-scale $[40,70,71]$. DNA methylation consists of the addition of a methyl group on the carbon in position 5' of a cytosine residue. Resulting in various patterns at the whole genome level (methylome), the dynamics of DNA methylation (establishment, maintenance, and active removal) are considered of great importance for plant development and response to environmental variations [60,72,73]. 


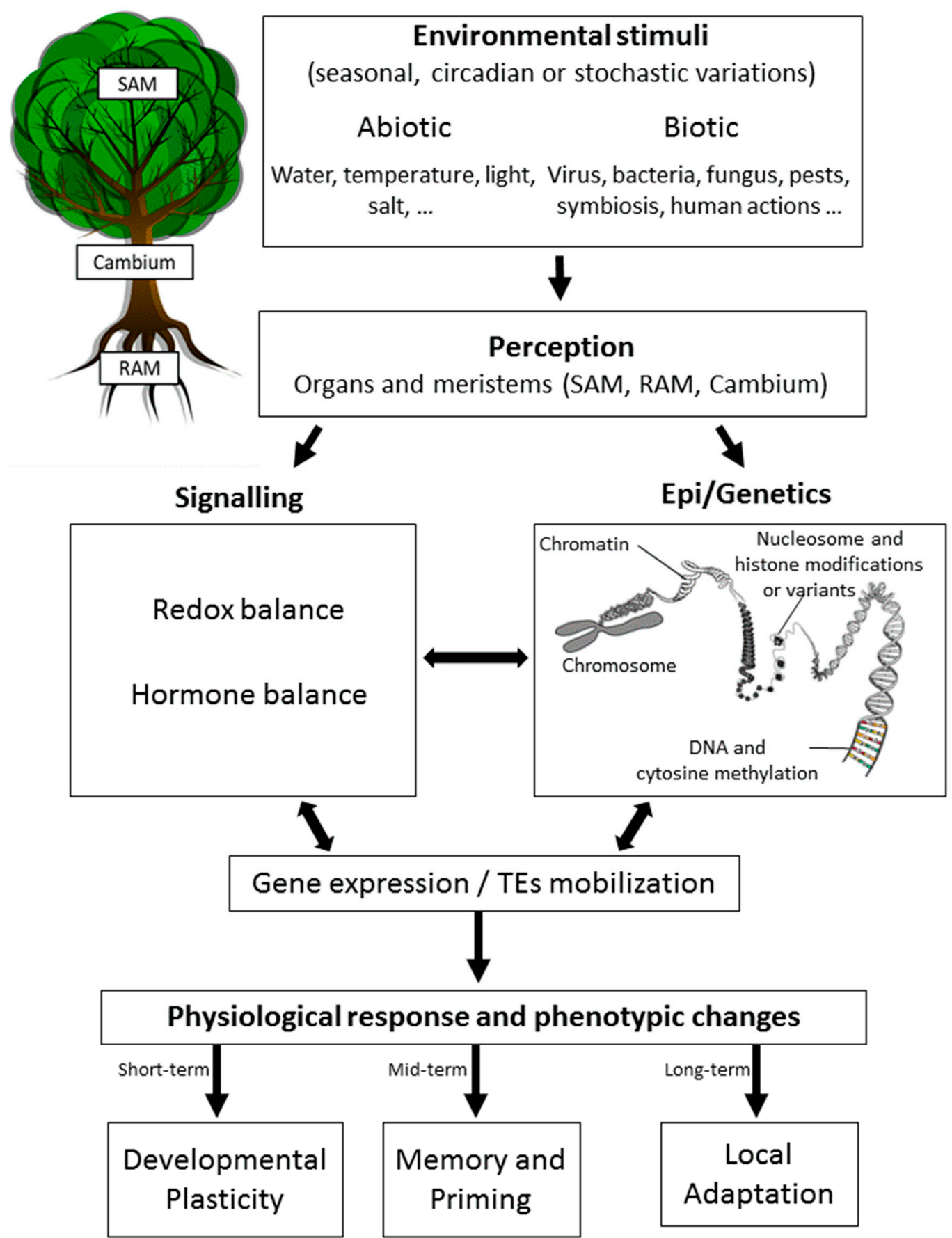

Figure 1. Epigenetic response to environmental changes in trees. Trees are known to recognize various abiotic and/or biotic stimuli occurring rhythmically (circadian or seasonal) or stochastically. These changes are perceived at different tissue levels, with most studies focusing on the leaves, roots, and meristems (SAM, shoot apical meristem; Cambium; or RAM, root apical meristem). Perception is then followed by signaling mechanisms that may include changes in the redox or hormonal balance, which have been shown to be related to epigenetic changes (chromatin remodeling, DNA methylation, non-coding RNA mechanisms (not shown), and histone modifications and variants). This complex crosstalk between signaling processes, epigenetics, and genetics results in an altered gene expression status and/or the mobilization of transposable elements (TEs). A physiological response is then observed together with phenotypic changes that allow trees to acclimate to the environmental changes initially sensed depending on the time-scale considered and the heritable transmission of epigenetic changes. 
In plants, methylation-induced modifications may either be reversible or retained during cell division (mitosis and intra-generational transmission) for a memory process as exemplified by vernalization [74-76] or passed on to the next generations (meiosis) as highlighted by the identification of natural epivariants [77-80] or artificially-induced epivariants and epigenetic recombinant inbred lines (EpiRILs) [81,82]. Studies with EpiRILs, where the recombinant offspring is created by crossing two parents with similar DNA sequences, but highly contrasting DNA methylation profiles have shown that part of the DNA methylation variation is inherited in a Mendelian manner [83]. Moreover, these EpiRILs show significant phenotypic variation in morphology, growth rate, and responses to biotic and abiotic stress [81,84-87].

Epigenetic diversity has thus emerged as a new source of broadened phenotypic variations for improving the adaptation of wild species to changing environments and ensuring the yield and quality of domesticated species whose genetic diversity has been eroded by intense breeding $[73,88,89]$. Epigenetic phenomena can affect plant phenotype and fitness, be stably inherited across multiple generations, and vary across populations and individuals, thus contributing to the ability of plants to colonize, adapt or evolve in variable environments [15,16,73,90-93]. Yona et al. (2015) [14] suggested that "organisms often adapt by progressing the adaptation spectrum, starting with rapidly attained physiological and epigenetic adaptations and culminating with slower long-lasting genetic ones". This suggests (i) direct interactions between epigenetics and genetics that can occur through the DNA methylation control of TEs transposition inducing mutations, but also (ii) an interplay between physiological responses and epigenetics (Figure 1) [94,95]. This last point has been recently proposed to occur through chromatin and hormones crosstalk [96-98] (Figure 1).

\section{Advances in Forest Tree Epigenetics: Memory and Priming}

Our knowledge of forest tree epigenetics has not evolved at the same pace as knowledge about other plant model organisms and crops. The studies on trees represent only a small proportion of those carried out in the field of Plant Sciences (Figure 2) and are limited to only a few species (see Table S1). Nevertheless, research in forest trees is now well-positioned to enter a productive phase due to the higher availability of genomic resources, especially if the associated costs become more accessible. The sequencing of forest tree genomes such as Populus trichocarpa [99], Picea abies [100], or Eucalyptus grandis [101] may have contributed to the increase in forest epigenetic studies over the last decade as such studies rely on high-quality genome sequence assemblies [40]. In addition to recent reviews on the methodologies for tree epigenomics, as well as features of forest tree breeding [39-41], we highlight thereafter recent advances in this fast-evolving field of research with a special focus on stress epigenetic memory and priming in trees.

Indeed, one example of memory-controlling plant response to pathogens, herbivore attacks, or abiotic stresses is defense priming [42,102-104]. The priming event is followed by a period of stress memory, storing information about the priming stress through an epigenetic phenomenon and resulting in a modified response upon recurring stress exposure or a sustained response after the priming stress [103]. This memory may last from several days to years for somatic stress memory, and in some cases, may even be extended to the offspring. Table S1 summarizes relevant studies that evidence the role of epigenetics in development, biotic and abiotic stress-responses, epigenetic memory, and stress priming, as well as initial and potential uses for tree breeding, conservation of genetic resources, or biotechnology. 


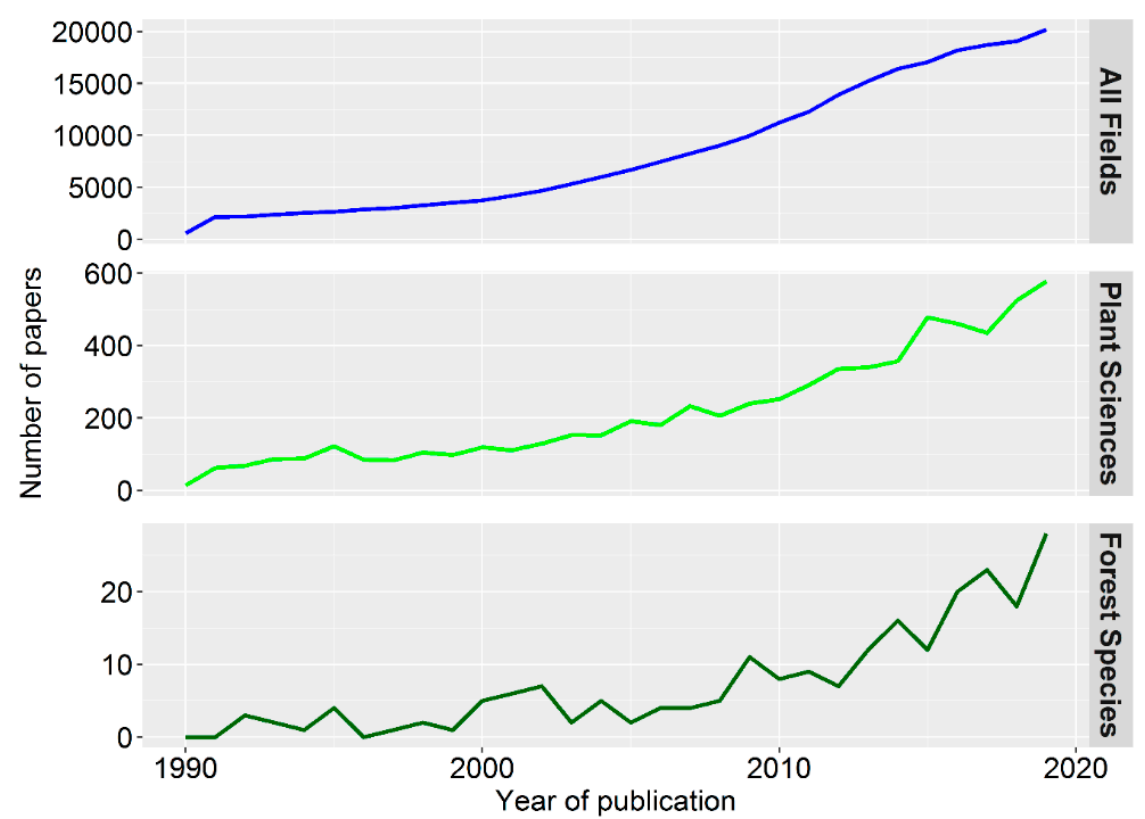

Figure 2. The number of papers on Epigenetics published per year from 1990 to 2019 (2020 being underway) in three Research Areas: all fields, plant sciences, and forest species. The number of studies was obtained from the Web of Science Core Collection (www.webofknowledge.com) with the topic search (TS) "epigenetics" and its variants (e.g. "epigenomics"). The main mechanisms behind epigenetics (DNA methylation, histone modification, chromatin remodeling, and non-coding RNA mechanisms) were also considered. An advanced search was therefore conducted as follows: TS $=$ (epigen* OR DNA methyl* OR histone OR chromatin remodel* OR (epigen* AND RNA)). All documents written in English and part of the Science Citation Index Expanded were examined. Results were then refined to retain the papers from the "Plant Sciences" Web of Science Category (adding "AND WC = Plant Sciences" to the query). Data was further filtered for epigenetic research in forest tree species by adding TS fields of "forest" and of the main forest tree genera studied (Picea/spruce, Pinus/pine, Populus/poplar, Quercus/oak, and Eucalyptus/eucalypt) and avoiding results referring to the "random-forest" method (NOT TS = random forest).

Only a few studies have paid attention to histone modifications, probably due to the fact that histone marks are numerous, labile, and difficult to analyze [105,106]. DNA methylation is one of the well-understood epigenetic marks and is commonly used in studies with forest trees. However, due to a lack of high-quality genome sequence assemblies for forest trees, most DNA methylation studies have focused on a global approach (High-Performance Liquid Chromatography) or a locus approach, such as MSAP (Methylation Sensitive Amplification Polymorphism), which uses methylation-sensitive restriction enzymes to identify methylated DNA fragments $[40,107,108]$ (Table S1). Despite the potential of such techniques in the absence of an assembled genome, they do not offer high resolution making it difficult to identify the specific targets (features) of DNA methylation variations. Once reference genomes are established and available [40], methods (such as Whole Genome Bisulfite Sequencing) can provide methylation at a single nucleotide resolution over the whole genome [71]. Another epigenetic mark that is attracting considerable attention in forest trees is ncRNAs (Table S1). Expression of specific microRNAs (miRNAs) has been associated with temperature-dependent epigenetic memory-controlling bud set/burst in Norway spruce and with habitat memory in poplar under phosphate starvation [109-112].

One striking point in Table S1 is that both DNA methylation and ncRNAs raise the fundamental question of the priming effect in forest trees. This epigenetic memory could help trees respond to recurrent biotic and/or abiotic stresses [113-115].

Studies in forest tree epigenetics in the context of biotic stresses remain limited. However, recent findings have highlighted variation in the epigenome of individuals infected by pathogens compared 
to healthy individuals. These variations have been observed at the methylome level for ash trees infected with the fungus Hymenoscyphus fraxineus [116]. A study of Paulownia fortunei infected with Paulownia witches'-broom disease showed a differential level in two histone methylations (H3K4me3, H3K36me3) and one histone acetylation (H3K9ac). The modifications of these histones seemed to be involved in the regulation of genes related to secondary metabolism, such as phenylpropanoid metabolism and the phytohormonal pathway, and to a lesser extent, genes related to plant-pathogen interactions [117].

Regarding abiotic disturbances, variation in DNA methylation levels has been reported following drought [118-126], salt stress [127-129], exposure to heavy metals [130], or temperature extremes [112,131-136]. Other investigations have reported changes in histone proteins related to water deficiency [137,138] or chronic radiation exposure [139], showing that these variations may occur at a genome-wide level, such as in Populus clones [119] or in mangrove trees (Laguncularia racemosa) [140]. Integrative studies have attempted to establish correlations between phenotypic or molecular responses and epigenetic modifications to highlight how epigenetic mechanisms potentially controlled the response of trees to environmental disturbances. For example, a study showed that salt exposure in Pyrus betulaefolia $(\mathrm{Pb})$ influences the expression of demethylases (DME), which highlights the important role of PbDME genes in response to salt stress [128]. Moreover, a study on Pinus radiata suggested that PrELIP1 (P. radiata Early Induced Protein 1), which has a role in resistance to photo-oxidative stress, is partly regulated by an epigenetic pathway during UV-B exposure [141].

For forest tree species, the best-known example of epigenetic memory is the environmental regulation of the performance of Picea abies progeny during seed production. Johnsen et al. (2005) [142] first suggested that seed production temperature and photoperiod interact to develop a long-lasting memory mechanism regulating phenology and frost hardiness, as well as bud burst timing [143] in $P$. abies progeny. This temperature-regulated epigenetic memory was associated with changes in gene expression either during its embryogenic development [142] or in the progenies [136,144]. Besnard et al. (2008) [145] further supported the existence of a memory mechanism in P. abies as maternal environmental conditions during reproductive steps only induced limited genotypic selection. This epigenetic memory could also explain the rapid acclimation in Norway of $P$. abies originating from Central Europe, which showed a bud set more similar to Norwegian seedlings than to seedlings from the same origin [146]. Evidence for the epigenetic basis of the memory formed in P. abies embryos influencing adult tree traits is well documented. Changes in the transcriptome of genetically identical P. abies somatic embryos during morphogenesis at 18 and $30^{\circ} \mathrm{C}$ were putatively based on chromatin modifications [110]. Moreover, the expression of a significant number of epigenetic regulators changed according to different epitype-inducing conditions, supporting the key role of DNA and histone methylation and small RNAs (sRNAs) to establish an epigenetic memory in P. abies [111]. The putative role of miRNAs in epigenetic regulation was suggested by the differential expression of specific miRNAs in seedlings of a full-sib family showing distinct epigenetic differences in bud set originated from seeds developed in cold and warm environments [147]. An in silico analysis of sRNAs further supported the involvement of miRNAs in the formation of epigenetic memory in somatic embryos of P. abies [148].

The influence of the maternal environment has also been shown to play an important role in the tolerance level of the offspring to various pathogens. Individuals from mother plants exposed to pathogens appear to be more tolerant to these same pathogens, and authors hypothesized that epigenetic mechanisms may be involved in this priming phenomenon [149,150]. Recently, Lamelas et al. (2020) [151] proposed the importance of epigenetic mechanisms for $P$. radiata heat stress tolerance and priming by evaluating the nuclear proteome and tissue DNA methylation dynamics of seedlings submitted to $45^{\circ} \mathrm{C}$ for 10 days, allowed to recover, and submitted to another stress cycle. Several proteins involved in epigenomic-driven gene regulation were identified. The authors state that a priming-induced epigenetic memory may develop novel approaches to improve pine survival under extreme heat stress in the context of climate change. Also, the application of the phytohormone methyl jasmonate on a 
stand of 48-year-old P. abies 35 days before exposure to the tree-killing bark beetle resulted in a primed state or immunological memory, which allowed these trees to resist insect attack [152]. The authors argue that the establishment of this priming memory is likely related to epigenetic mechanisms, such as DNA methylation and histone modifications as in Arabidopsis [153], but acknowledge that further studies are needed.

Recent studies have suggested that epigenetic mechanisms are also involved in drought-induced developmental plasticity through the regulation of the phytohormonal pathway in the shoot apical meristem (SAM) [98,123,124]. Developmental plasticity [154] involves the pluripotency of stem cells located in meristems through the fine-tuning control of cell identity genes by hormones [155]. Crosstalk between chromatin and phytohormones in the meristem is supported by (i) direct control of phytohormone signaling on chromatin modifiers or marks, and vice versa, and (ii) their effects on cell identity genes in the meristem, on the stabilization of gene expression beyond the initial hormonal signal, and on the integration of separate hormones by chromatin acting as a hub. This process could explain, at least in part, the epigenetic memory and priming of organs after recurrent stress.

An environmentally-induced epigenetic memory that may facilitate tree acclimation has been suggested in winter-dormant SAMs of field-grown poplar trees [124]. Trees grown under moderate drought conditions during the vegetative period exhibited differentially methylated regions on stress-responsive genes and hormonal pathways in winter-dormant SAMs six months later, suggesting an epigenetic memory mediated by DNA methylation [124]. A significant decrease in global DNA methylation has also been detected in winter-dormant SAMs from natural populations of black poplar subjected to a summer-drought [125]. Furthermore, Le Gac et al. (2019) [126] showed that the first leaf emerging from SAMs also exhibited changes in DNA methylation under variable water availability. This result suggests a possible mitotic transmission (memory) from the SAM to the emerging leaf formed during the stress period. Other studies have reported an epigenetic memory in trees in response to drought with poplar transcriptomics depending on clone history [119], or in response to phosphorus nutrition with site-dependent growth of clonal Populus trichocarpa [112].

Altogether, although it is well-established that global changes represent a higher risk for insect and disease outbreaks in forests worldwide, there is a lack of epigenetic studies focusing on the response of forest species to biotic stresses. Most of the work in forest tree epigenetics is related to the response of several species to abiotic stresses, mainly drought and extreme temperatures. Moreover, our understanding of what functional traits allow plants to thrive under stressful conditions and their relationships with epigenetic mechanisms is lacking. In poplar and Norway spruce, epigenetic memory has proven to provide trees with adaptive plasticity, based on previous environmental conditions that facilitate plant responses to new challenges (Table S1). In line with these findings, epigenetics has emerged as a potential tool to understand and improve priming strategies against both biotic and abiotic stresses.

\section{Promises of Epigenetics for Tree Improvement, Breeding, Conservation of Genetic Resources and Forest Management}

The potential of epigenetics in plant breeding is already being considered in crops [73,88,89,156-158]. Only limited studies have been implemented with trees, and results coming from crops will need to be adapted to fit with the specific features of tree breeding and forest management [40]. Although most of the studies on forest trees have focused on the role of epigenetics in tree development, and response to environmental changes and priming (Table S1), recent studies have pointed out the potential relevance of epigenetics in tree improvement. Three main approaches using epigenetics may be foreseen: (i) Exploit natural or artificially-induced epigenetic diversity; (ii) use epigenetic marks in addition to classic genetic markers for trait improvement with trans-omics approach [159], statistics and modeling, and (iii) use epigenome editing [160]. Epigenetics could be used to expand the material for tree breeders that may be used by sexual or asexual propagation methods. 
The best-known example in trees for exploiting natural or induced epigenetic diversity is the existence of an epigenetic memory mechanism that operates during embryo development in Norway spruce (see above section). This process adjusts the timing of bud burst in the progeny, but also in genetically identical epitypes in a manner usually associated with ecotypes in accordance with the temperature conditions during embryogenesis [136,142-144,146]. Kvaalen and Johnsen (2008) [143] demonstrated that environmentally induced epigenetic memory during somatic embryogenesis can give similar results for phenology as to those produced by provenance separation of $4-6^{\circ}$ latitude. Environmentally induced epigenetic memory during somatic embryogenesis could potentially be used in tree breeding to prime trees regarding their phenology for their first years of plantation along a latitudinal gradient. This promising application opens up many possibilities for forest tree research considering the increasing literature on tree priming (Table S1), and unravels the importance of epigenetic natural diversity that should be taken into consideration for forest breeding, conservation of genetic resources and forest management and protection. Another example of exploiting natural epigenetic variation is emerging from the role of epigenetics in tree heterosis that has been evaluated in Populus deltoides [161]. Findings indicate that methylation patterns of the two P. deltoides parental lines are both partially and dynamically passed on to their intraspecific hybrids, resulting in a non-additive methylation pattern in F1 hybrids. However, studies on epigenetic and heterosis are still necessary for trees and will have to be evaluated by tree breeders.

Another perspective of forest tree epigenetics comes from studies conducted on Arabidopsis and crops concerning sRNAs and cross-kingdom RNA interference (RNAi) [162]. Cai et al. (2018) [163] have shown that Arabidopsis has adapted its exosome-mediated cross-kingdom RNAi as part of its immune responses against pathogens. Pathogens and pests can thus be controlled by sRNAs, targeting their essential or pathogenicity genes, raising the possibility of plants to be protected from diseases by a novel eco-friendly, durable, and highly specific RNA fungicide or pesticide [163,164]. In addition, there is growing evidence to indicate that epigenetic mechanisms directly participate in plant immune responses. However, the evidence of transgenerational inheritance of pathogen-induced defense priming is still a matter of debate [165]. Studies have shown that biotic stresses can also trigger an increase in the overall level of genomic methylation. Curiously, the methylation levels of some pathogen responses or resistance genes are reduced [166]. We still need to understand exactly how epigenetics controls trees' defenses against disease to then translate this knowledge into practical actions. By exploring natural and induced resistance, we may implement new breeding strategies for preventing disease while reducing the global reliance on harmful pesticides, a field of research still in its infancy for trees.

The application of epigenetic markers to tree breeding has been tested over the last few years, including studies highlighting the extent and variation of genome-wide DNA methylation in natural populations of trees. Ci et al. (2015) [167] investigated the variation in DNA methylation and whether this variation correlates with important plant traits, including leaf shape and photosynthesis in Populus simonii, indicating that epigenetics bridges environmental and genetic factors in affecting plant growth and development. Sow et al. (2018) [125] reported the first estimate of narrow-sense heritability $\left(\mathrm{h}^{2}\right)$ and phenotypic differentiation (Pst) for global DNA methylation in trees by assessing global DNA methylation variations in Populus nigra clones from natural populations under varying soil water availability. Regardless of water regimes, values of $\mathrm{h}^{2}$ and Pst were comparable to those found for shoot biomass production, a known heritable trait in poplar. Therefore, global DNA methylation, being genetically and environmentally determined in these populations, could be used as a potential marker for population differentiation, performance, and selection under stressful conditions. To explore the epigenetic diversity in breeding programs, we need to expand our knowledge regarding the link between DNA methylation and economic traits in forest trees. Ma et al. (2012) [168] investigated 130 intraspecific hybrids of Populus tomentosa and concluded that the regions defined by the MSAP candidate markers are linked to genes that are essential for photosynthetic traits that respond to DNA methylation which affect growth traits. 
The potential of epigenetic markers in quantitative breeding approaches has been recently suggested by Baison et al. (2019) [169]. The authors identified 52 QTLs (Quantitative Trait Loci) of wood properties in Norway spruce for marker-assisted breeding. However, these QTLs explain a small proportion of the genetic variation, in line with previous studies examining genetic variation in complex traits in coniferous species using forward genetic approaches. They suggest that this could be due to several factors, including epigenetic variation, highlighting the need for sophisticated epi/genotyping tools, as well as a combination of advanced statistical models, such as regional heritability mapping. Recently, Champigny et al. (2019) [170] applied statistical learning experiments to genetically diverse populations of Populus balsamifera trees grown at two common garden sites and showed that traits in novel genotypes can be modelled using small numbers of methylated DNA predictors. Indeed, significant phenotypic variances in quantitative traits of the wood were explained by the natural variation of DNA methylation, such as total biomass (57.5\%), wood density $(40.9 \%)$, soluble lignin (25.3\%), and carbohydrate content in the cell wall (mannose: $44.8 \%$ ). The authors proposed that DNA methylation-based models can be used as a strategy to validate the identity, provenance, or quality of agroforestry products. While this approach presents innovative perspectives for forest trees, it should be evaluated in terms of cost, technical, and analytical efforts.

The last approach to use epigenetics for tree improvement is epigenome editing, i.e., a type of genetic engineering in which the epigenome is modified at specific sites using engineered molecules targeted to those sites. Genome editing in trees has been recently reviewed by Bewg et al. (2018) [160], suggesting a great potential for stable CRISPR-induced mutations and associated phenotypes over multiple clonal generations. Authors suggest that this technology can be used for the commercial production of elite trees that relies on vegetative propagation. The potential of epigenome editing to control recombination in plant breeding has been recently reviewed [171]. Manipulating the rate and positions of crossovers to increase the genetic variation accessible to breeders is of main interest. Epi/genome editing at desired sites of recombination, and manipulation of crossovers factors, are applicable approaches for achieving this goal, reducing the time and expense associated with traditional breeding, revealing inaccessible genetic diversity, and increasing control over the inheritance of preferred haplotypes [171]. However, there is no study on epigenome editing in trees, and the feasibility of such technological advances, depending on use regulations in different countries, will have to be evaluated by tree breeders in the future.

\section{Gaps in Knowledge and Future Challenges}

Although the conceptual role of epigenetics in trees is established (see Figure 1) and supported by an increasing number of articles (Figure 2 and Table S1), there is still a long way to go before one will make use of this adaptive potential in forest management. Most studies in forest trees have focused on how developmental and/or environmental interactions affect epigenetic marks (particularly DNA methylation), mainly using descriptive or correlative approaches between phenotypic traits and epi/genomics data. Recently, Alonso et al. (2019) [95] proposed suitable approaches to detect links between epigenetic variation and plant (Arabidopsis and crop) functional phenotypic traits for biotic stress. The strategy combines the use of epimutants, drugs [172], or wild populations across environmental gradients with direct phenotyping of fitness traits to study somatic or transgenerational relationships after stress exposure. The authors proposed (i) "concurrent analysis of epigenetic variation and phenotypic trait variation, including plant fitness between individuals exposed to contrasted biotic interactions" and (ii) "analysis of specific loci and physiological pathways to clarify the epigenetic contribution to the stabilization of environmentally induced phenotypes (priming) or across generations" to gain insights into functional relationships. In addition to these recommendations, we propose a complementary methodological plan for epi/genetics in trees by (i) using both forward and reverse (epi)genetic approaches and developing population epigenomics $[173,174]$, (ii) assessing the effects of multiple, potentially interacting, stressful conditions (intensity, duration, frequency, interaction), (iii) favoring experimental designs with growing conditions in common garden to get as 
close as possible to natural conditions, (iv) using kinetics approaches by sampling biological material along a developmental gradient for a better understanding of the molecular chain acting from short to long term during development $\times$ environment interactions [154], (v) taking into account tree features (species, genotype, physiological and chronological ages, organs, tissues), but also the geographic origin, clone history, clonal propagation vs. sexual reproduction, and all features of breeding, management of genetic resources and forestry, and (vi) developing a trans-omics approach [159] to overcome the lack of comprehensive understanding and the information gap regarding interaction across multiple -omic layers. Trans-omics is an approach for reconstructing molecular networks by connecting multiple -omic data. To reach that purpose, diverse statistical and modeling analyses must be tested to move from correlative to causal inference and predictions [40], as developed in human brain research (for example, see Reference [175]).

In addition, this methodological plan for epi/genetics in trees must be adapted to natural- and artificial-based forest management. In artificial-based forest management, epigenetics could improve the response of planted trees to stress by promoting stress memory during the breeding process or at the very beginning of the seedling stage. While this idea is attractive, its implementation can face important challenges. First, because trees are long-lived organisms, they are highly susceptible to numerous stresses at various stages of their lifespan, and this is particularly true with global change. Hence, for stress memory to be useful, research in epigenetics should focus on the long-term effect of stress memory. Second, in the context of global change, trees are also susceptible to stresses that are variable in their nature, such as droughts, thaw-freeze events, early or late frosts, or insect defoliations.

In natural-based forest management, it is impossible to have a direct effect on regeneration (i.e., choosing a specific seed to grow as a tree) through breeding programs. However, recent research shows that epigenetics could be, on the one hand, partly responsible for the large intraspecific plasticity observed in plants, and on the other hand, that stressful conditions can induce epigenetic responses. These findings appear promising because we may not yet have seen the extent of phenotypic plasticity for some species. Moreover, if further research can identify how mature tree species respond to various stresses "epigenetically", this opens the door to new ideas in terms of silvicultural treatments to take advantage of this phenotypic plasticity. For example, if the progeny from trees that were under drought stress during seed formation show higher resistance to drought, forest managers could develop strategies to favor their germination and the further development of this particular seedling cohort.

The advent of next-generation sequencing technologies pushed by the emergent need to explore epi/genetic diversity in response to climate challenges $[39,116,176,177]$ contributed to the initiation and progress of research of tree epigenomics [40]. Genomics will play a major role not only in unveiling the epigenetic mechanisms underlying adaptation, but also in developing and implementing innovative management actions to preserve forest adaptability and identify traits for selection in breeding programs. To achieve these goals, efforts are needed to establish forest tree reference (epi)genome sequences, to determine how to apply sequencing technologies to understand adaptation, and to develop resources for storing, accessing, and sharing forestry data $[39,40,178]$. As forests and trees have shown an incredible ability to survive through the occurrence of various stresses for centuries, there is a need to understand to what extent epigenetics has played a role in this resistance and resilience of forests to past stressors, such as droughts, extreme heat events, insect defoliation, and dieback episodes. This question is hard to answer as epigenetic analyses require "fresh" material, but it might be possible to identify growth patterns in dendrochronological studies that support this hypothesis. No matter if it is with dendrochronology or by other means, epigenetic researchers would benefit from engaging collaborations with other disciplines to confirm the importance of epigenetics in forest resistance and resilience to past stresses. This is one of the concerns being addressed within the research project EPITREE (Evolutionary and functional impact of epigenetic variation in forest TREEs; ANR-17-CE32, https://www6.inrae.fr/epitree-project/) that should encourage translational research in the field of forest research. The recent EPI-CATCH Cost Action (CA19125; https:/www.cost.eu/actions/CA19125/) has created an international network where researchers and stakeholders share and discuss information to 
improve laboratory epigenetic methodologies, in silico data analysis, and the integration of epigenomic data with other -omic data (genomic, transcriptomic, proteomic, phenomic, etc.) in crops, including relevant forest species. The knowledge and methodologies will be discussed with a focus on the investigation of epigenetic mechanisms modulating plant adaptation to environmental stresses driven by climate change.

Finally, priming seems to be rising as an interesting new research line in trees with the contribution from scientists worldwide, as it is evidenced by the "Priming in Trees Consortium" (https://lunadiezlab. com/priming-in-trees-consortium/). This alliance aims to understand the priming mechanism itself, its durability, and implementation in forests as a promising solution for current and future threats. Epigenetics has been identified as a key contributor to the priming mechanism, and thus, deeper studies that focus on unveiling the epigenetic mechanisms involved in priming in forest tree species are required. Besides identifying the epigenetic mechanisms involved in stress-response, it is important to apply this knowledge to the conservation of forest genetic resources, breeding, and management.

Supplementary Materials: The following are available online at http://www.mdpi.com/1999-4907/11/9/976/s1. Table S1: Current state of epigenetics in trees for development, abiotic stress or priming, biotic stress or priming, and markers, breeding and biotechnology topics.

Author Contributions: S.M. suggested and designed the article. J.A., Z.R. and J.V. designed the figures and table and wrote a first draft of the manuscript and revised version with the help of M.D.S., R.F., C.M., G.P., P.N. All authors have read and agreed to the published version of the manuscript.

Funding: This research was funded by ANR France, within the project EPITREE to S.M. (ANR-17-CE32-0009-01; https://www6.inrae.fr/epitree-project_eng/) and by FCT (Fundação para a Ciência e a Tecnologia)/ MCTES through the financial support to CESAM to G.P (UIDP/50017/2020+UIDB/50017/2020). J.A., Z.R., and J.V. PhD grants are supported by FCT (SFRH/BD/120967/2016), Canada Chair in forest resilience to global changes and Conseil Régional Centre Val de Loire, respectively.

Acknowledgments: We thank EPICATCH cost Action (CA19125), GDR3E and "Priming in Trees Consortium" for their valuable support to promote works in epigenetics in trees. We apologize to all colleagues whose work was not cited due to length limitations.

Conflicts of Interest: The authors declare no conflict of interest.

\section{References}

1. Food and Agriculture Organization (FAO). Forests Pathways to Sustainable Development; State of the world's forests; Food and Agriculture Organization: Rome, Italy, 2018.

2. Adams, H.D.; Macalady, A.K.; Breshears, D.D.; Allen, C.D.; Stephenson, N.L.; Saleska, S.R.; Huxman, T.E.; McDowell, N.G. Climate-Induced Tree Mortality: Earth System Consequences. Eos 2010, 91, 153-154. [CrossRef]

3. Allen, C.D.; Macalady, A.K.; Chenchouni, H.; Bachelet, D.; McDowell, N.; Vennetier, M.; Kitzberger, T.; Rigling, A.; Breshears, D.D.; Hogg, E.; et al. A global overview of drought and heat-induced tree mortality reveals emerging climate change risks for forests. For. Ecol. Manag. 2010, 259, 660-684. [CrossRef]

4. Anderegg, W.; Klein, T.; Bartlett, M.; Sack, L.; Pellegrini, A.F.A.; Choat, B.; Jansen, S. Meta-analysis reveals that hydraulic traits explain cross-species patterns of drought-induced tree mortality across the globe. Proc. Natl. Acad. Sci. USA 2016, 113, 5024-5029. [CrossRef] [PubMed]

5. Messier, C.; Bauhus, J.; Doyon, F.; Maure, F.; Sousa-Silva, R.; Nolet, P.; Mina, M.; Aquilué, N.; Fortin, M.J.; Puettmann, K. The functional complex network approach to foster forest resilience to global changes. For. Ecosyst. 2019, 6, 21. [CrossRef]

6. Nolet, P.; Kneeshaw, D. Extreme events and subtle ecological effects: Lessons from a long-term sugar maple-American beech comparison. Ecosphere 2018, 9, e02336. [CrossRef]

7. Denny, M.W.; Hunt, L.J.H.; Miller, L.P.; Harley, C.D.G. On the prediction of extreme ecological events. Ecol. Monogr. 2009, 79, 397-421. [CrossRef]

8. Millar, C.I.; Stephenson, N.L. Temperate forest health in an era of emerging megadisturbance. Science 2015, 349, 823-826. [CrossRef] [PubMed]

9. Bruce, T.J.A.; Matthes, M.C.; Napier, J.A.; Pickett, J.A. Stressful "memories" of plants: Evidence and possible mechanisms. Plant Sci. 2007, 173, 603-608. [CrossRef] 
10. Feeley, K.J.; Rehm, E.M.; Machovina, B. Perspective: The responses of tropical forest species to global climate change: Acclimate, adapt, migrate, or go extinct? Front. Biogeogr. 2012, 4. [CrossRef]

11. Fox, R.J.; Donelson, J.M.; Schunter, C.; Ravasi, T.; Gaitán-Espitia, J.D. Beyond buying time: The role of plasticity in phenotypic adaptation to rapid environmental change. Philos. Trans. R. Soc. B Biol. Sci. 2019, 374, 20180174. [CrossRef]

12. Parmesan, C. Ecological and Evolutionary Responses to Recent Climate Change. Annu. Rev. Ecol. Evol. Syst. 2006, 37, 637-669. [CrossRef]

13. Davis, M.B. Range Shifts and Adaptive Responses to Quaternary Climate Change. Science 2001, 292, 673-679. [CrossRef] [PubMed]

14. Yona, A.H.; Frumkin, I.; Pilpel, Y. A Relay Race on the Evolutionary Adaptation Spectrum. Cell 2015, 163, 549-559. [CrossRef] [PubMed]

15. Herrel, A.; Joly, D.; Danchin, E. Epigenetics in ecology and evolution. Funct. Ecol. 2020, 34, 381-384. [CrossRef]

16. Marin, P.; Genitoni, J.; Barloy, D.; Maury, S.; Gibert, P.; Ghalambor, C.K.; Vieira, C. Biological invasion: The influence of the hidden side of the (epi)genome. Funct. Ecol. 2019, 34, 385-400. [CrossRef]

17. Solarik, K.A.; Cazelles, K.; Messier, C.; Bergeron, Y.; Gravel, M. Priority effects will impede range shifts of temperate tree species into the boreal forest. J. Ecol. 2019, 108, 1155-1173. [CrossRef]

18. Heilmeier, H. Functional traits explaining plant responses to past and future climate changes. Flora Morphol. Distrib. Funct. Ecol. Plants 2019, 254,1-11. [CrossRef]

19. Rey, O.; Eizaguirre, C.; Angers, B.; Soares, M.; Sagonas, K.; Prunier, J.G.; Blanchet, S. Linking epigenetics and biological conservation: Towards a conservation epigenetics perspective. Funct. Ecol. 2019, 34, 414-427. [CrossRef]

20. Alfaro, R.I.; Fady, B.; Vendramin, G.G.; Dawson, I.K.; Fleming, R.A.; Sáenz-Romero, C.; Lindig-Cisneros, R.A.; Murdock, T.; Vinceti, B.; Navarro, C.M.; et al. The role of forest genetic resources in responding to biotic and abiotic factors in the context of anthropogenic climate change. For. Ecol. Manag. 2014, 333, 76-87. [CrossRef]

21. Alberto, F.J.; Aitken, S.N.; Alía, R.; Gonzalez-Martinez, S.C.; Hänninen, H.; Kremer, A.; Lefèvre, F.; Lenormand, T.; Yeaman, S.; Whetten, R.; et al. Potential for evolutionary responses to climate change-Evidence from tree populations. Glob. Chang. Biol. 2013, 19, 1645-1661. [CrossRef]

22. Laitinen, R.A.E.; Nikoloski, Z. Genetic basis of plasticity in plants. J. Exp. Bot. 2018, 70, 739-745. [CrossRef] [PubMed]

23. Violle, C.; Navas, M.-L.; Vile, D.; Kazakou, E.; Fortunel, C.; Hummel, I.; Garnier, E. Let the concept of trait be functional! Oikos 2007, 116, 882-892. [CrossRef]

24. Bartlett, M.K.; Klein, T.; Jansen, S.; Choat, B.; Sack, L. The correlations and sequence of plant stomatal, hydraulic, and wilting responses to drought. Proc. Natl. Acad. Sci. USA 2016, 113, 13098-13103. [CrossRef]

25. Volaire, F. A unified framework of plant adaptive strategies to drought: Crossing scales and disciplines. Glob. Chang. Biol. 2018, 24, 2929-2938. [CrossRef] [PubMed]

26. Buckley, T.N. The control of stomata by water balance. New Phytol. 2005, 168, 275-292. [CrossRef] [PubMed]

27. Klein, $\mathrm{T}$. The variability of stomatal sensitivity to leaf water potential across tree species indicates a continuum between isohydric and anisohydric behaviours. Funct. Ecol. 2014, 28, 1313-1320. [CrossRef]

28. Kozlowski, T.T.; Pallardy, S.G. Acclimation and Adaptive Responses of Woody Plants to Environmental Stresses. Bot. Rev. 2002, 68, 270-334. [CrossRef]

29. Bartlett, M.K.; Scoffoni, C.; Sack, L. The determinants of leaf turgor loss point and prediction of drought tolerance of species and biomes: A global meta-analysis. Ecol. Lett. 2012, 15, 393-405. [CrossRef]

30. Bartlett, M.K.; Zhang, Y.; Kreidler, N.; Sun, S.; Ardy, R.C.; Cao, K.F.; Sack, L. Global analysis of plasticity in turgor loss point, a key drought tolerance trait. Ecol. Lett. 2014, 17, 1580-1590. [CrossRef]

31. Bogeat-Triboulot, M.B.; Brosché, M.; Renaut, J.; Jouve, L.; Le Thiec, D.; Fayyaz, P.; Vinocur, B.; Witters, E.; Laukens, K.; Teichmann, T;; et al. Gradual Soil Water Depletion Results in Reversible Changes of Gene Expression, Protein Profiles, Ecophysiology, and Growth Performance in Populus euphratica, a Poplar Growing in Arid Regions. Plant Physiol. 2006, 143, 876-892. [CrossRef]

32. Wu, F.; Bao, W.; Li, F.; Wu, N. Effects of drought stress and N supply on the growth, biomass partitioning and water-use efficiency of Sophora davidii seedlings. Environ. Exp. Bot. 2008, 63, 248-255. [CrossRef] 
33. Poorter, H.; Niklas, K.J.; Reich, P.B.; Oleksyn, J.; Poot, P.; Mommer, L. Biomass allocation to leaves, stems and roots: Meta-analyses of interspecific variation and environmental control. New Phytol. 2011, 193, 30-50. [CrossRef] [PubMed]

34. Brodribb, T.J. Progressing from 'functional' to mechanistic traits. New Phytol. 2017, 215, 9-11. [CrossRef]

35. Gillison, A.N. Plant functional indicators of vegetation response to climate change, past present and future: I. Trends, emerging hypotheses and plant functional modality. Flora Morphol. Distrib. Funct. Ecol. Plants 2019, 254, 12-30. [CrossRef]

36. Cornelissen, J.H.C.; Lavorel, S.; Garnier, E.; Díaz, S.; Buchmann, N.; Gurvich, D.E.; Reich, P.B.; Ter Steege, H.; Morgan, H.D.; van der Heijden, M.G.A.; et al. A handbook of protocols for standardised and easy measurement of plant functional traits worldwide. Aust. J. Bot. 2003, 51, 335-380. [CrossRef]

37. Lind, B.M.; Menon, M.; Bolte, C.E.; Faske, T.M.; Eckert, A.J. The genomics of local adaptation in trees: Are we out of the woods yet? Tree Genet. Genomes 2018, 14, 29. [CrossRef]

38. Bräutigam, K.; Vining, K.J.; Placette, C.L.; Fossdal, C.G.; Mirouze, M.; Marcos, J.G.; Fluch, S.; Fraga, M.F.; Guevara, M.Á.; Abarca, D.; et al. Epigenetic regulation of adaptive responses of forest tree species to the environment. Ecol. Evol. 2013, 3, 399-415. [CrossRef]

39. Plomion, C.; Bastien, C.; Bogeat-Triboulot, M.B.; Bouffier, L.; Déjardin, A.; Duplessis, S.; Fady, B.; Heuertz, M.; Le Gac, A.L.; Le Provost, G.; et al. Forest tree genomics: 10 achievements from the past 10 years and future prospects. Ann. For. Sci. 2016, 73, 77-103. [CrossRef]

40. Sow, M.D.; Allona, I.; Ambroise, C.; Conde, D.; Fichot, R.; Gribkova, S.; Jorge, V.; Le-Provost, G.; Pâques, L.; Plomion, C.; et al. Epigenetics in Forest Trees. In Advances in Botanical Research; Elsevier: Amsterdam, The Netherlands, 2018; Volume 88, pp. 387-453.

41. Carbó, M.; Iturra, C.; Correia, B.; Colina, F.J.; Meijón, M.; Álvarez, J.M.; Cañal, M.J.; Hasbún, R.; Pinto, G.; Valledor, L. Epigenetics in Forest Trees: Keep Calm and Carry On. In Epigenetics in Plants of Agronomic Importance: Fundamentals and Applications; Alvarez-Venegas, R., De-la-Peña, C., Casas-Mollano, J.A., Eds.; Springer International Publishing: Cham, Switzerland, 2019; pp. 381-403. [CrossRef]

42. Mauch-Mani, B.; Baccelli, I.; Luna, E.; Flors, V. Defense Priming: An Adaptive Part of Induced Resistance. Annu. Rev. Plant Biol. 2017, 68, 485-512. [CrossRef]

43. Waddington, C.H. Canalization of development and the inheritance of acquired characters. Nature 1942, 150, 563-565. [CrossRef]

44. Waddington, C.H. Organisers and Genes; The Cambridge University Press: Cambridge, UK, 1940; p. 166.

45. Tronick, E.; Hunter, R.G. Waddington, Dynamic Systems, and Epigenetics. Front. Behav. Neurosci. 2016, 10, 10. [CrossRef] [PubMed]

46. Bossdorf, O.; Richards, C.L.; Pigliucci, M. Epigenetics for ecologists. Ecol. Lett. 2007, 11, 106-115. [CrossRef] [PubMed]

47. Richards, E.J. Natural epigenetic variation in plant species: A view from the field. Curr. Opin. Plant Biol. 2011, 14, 204-209. [CrossRef] [PubMed]

48. Ledón-Rettig, C.C. Ecological Epigenetics: An Introduction to the Symposium. Integr. Comp. Biol. 2013, 53, 307-318. [CrossRef]

49. Maher, B. Personal genomes: The case of the missing heritability. Nature 2008, 456, 18-21. [CrossRef]

50. Danchin, E. Avatars of information: Towards an inclusive evolutionary synthesis. Trends Ecol. Evol. 2013, 28, 351-358. [CrossRef]

51. Xiao, S.; Cao, X.; Zhong, S. Comparative epigenomics: Defining and utilizing epigenomic variations across species, time-course, and individuals. Wiley Interdiscip. Rev. Syst. Boil. Med. 2014, 6, 345-352. [CrossRef]

52. Roudier, F.; Ahmed, I.; Bérard, C.; Sarazin, A.; Mary-Huard, T.; Cortijo, S.; Bouyer, D.; Caillieux, E.; Duvernois-Berthet, E.; Al-Shikhley, L.; et al. Integrative epigenomic mapping defines four main chromatin states in Arabidopsis. EMBO J. 2011, 30, 1928-1938. [CrossRef]

53. Bannister, A.J.; Kouzarides, T. Regulation of chromatin by histone modifications. Cell Res. 2011, 21, 381-395. [CrossRef] [PubMed]

54. Becker, P.B.; Hörz, W. ATP-Dependent Nucleosome Remodeling. Annu. Rev. Biochem. 2002, 71, $247-273$. [CrossRef]

55. Harikumar, A.; Meshorer, E. Chromatin remodeling and bivalent histone modifications in embryonic stem cells. EMBO Rep. 2015, 16, 1609-1619. [CrossRef] [PubMed] 
56. Matzke, M.A.; Mosher, R.A. RNA-directed DNA methylation: An epigenetic pathway of increasing complexity. Nat. Rev. Genet. 2014, 15, 394-408. [CrossRef] [PubMed]

57. Kawashima, T.; Lorković, Z.J.; Nishihama, R.; Ishizaki, K.; Axelsson, E.; Yelagandula, R.; Kohchi, T.; Berger, F. Diversification of histone H2A variants during plant evolution. Trends Plant Sci. 2015, 20, 419-425. [CrossRef] [PubMed]

58. Hussey, S.G.; Mizrachi, E.; Groover, A.; Berger, D.K.; Myburg, A.A. Genome-wide mapping of histone H3 lysine 4 trimethylation in Eucalyptus grandis developing xylem. BMC Plant Biol. 2015, 15, 1-14. [CrossRef] [PubMed]

59. Jiang, D.; Berger, F. DNA replication-coupled histone modification maintains Polycomb gene silencing in plants. Science 2017, 357, 1146-1149. [CrossRef]

60. Zhang, H.; Lang, Z.; Zhu, J.-K. Dynamics and function of DNA methylation in plants. Nat. Rev. Mol. Cell Biol. 2018, 19, 489-506. [CrossRef]

61. Zhao, H.; Winogradoff, D.; Dalal, Y.; Papoian, G.A. The Oligomerization Landscape of Histones. Biophys. J. 2019, 116, 1845-1855. [CrossRef]

62. Zhu, H.; Wang, G.; Qian, J. Transcription factors as readers and effectors of DNA methylation. Nat. Rev. Genet. 2016, 17, 551-565. [CrossRef]

63. Biswas, S.; Rao, C.M. Epigenetic tools (The Writers, The Readers and The Erasers) and their implications in cancer therapy. Eur. J. Pharmacol. 2018, 837, 8-24. [CrossRef]

64. Zemach, A.; McDaniel, I.E.; Silva, P.; Zilberman, D. Genome-Wide Evolutionary Analysis of Eukaryotic DNA Methylation. Science 2010, 328, 916-919. [CrossRef]

65. Niederhuth, C.E.; Schmitz, R.J. Putting DNA methylation in context: From genomes to gene expression in plants. Biochim. Biophys. Acta Bioenerg. 2017, 1860, 149-156. [CrossRef]

66. Bewick, A.J.; Schmitz, R.J. Gene body DNA methylation in plants. Curr. Opin. Plant Biol. 2017, 36, 103-110. [CrossRef]

67. Mirouze, M.; Reinders, J.; Bucher, E.; Nishimura, T.; Schneeberger, K.; Ossowski, S.; Cao, J.; Weigel, D.; Paszkowski, J.; Mathieu, O. Selective epigenetic control of retrotransposition in Arabidopsis. Nature 2009, 461, 427-430. [CrossRef]

68. Slotkin, R.K.; Vaughn, M.W.; Borges, F.; Tanurdzic, M.; Becker, J.D.; Feijó, J.A.; Martienssen, R.A. Epigenetic Reprogramming and Small RNA Silencing of Transposable Elements in Pollen. Cell 2009, 136, 461-472. [CrossRef]

69. Feng, S.; Cokus, S.J.; Schubert, V.; Zhai, J.; Pellegrini, M.; Jacobsen, S.E. Genome-wide Hi-C Analyses in Wild-Type and Mutants Reveal High-Resolution Chromatin Interactions in Arabidopsis. Mol. Cell 2014, 55, 694-707. [CrossRef]

70. Kurdyukov, S.; Bullock, M. DNA Methylation Analysis: Choosing the Right Method. Biology 2016, 5, 3. [CrossRef]

71. Yong, W.S.; Hsu, F.M.; Chen, P.Y. Profiling genome-wide DNA methylation. Epigenetics Chromatin 2016, 9, 26. [CrossRef] [PubMed]

72. Zhang, X.; Yazaki, J.; Sundaresan, A.; Cokus, S.; Chan, S.W.-L.; Chen, H.; Henderson, I.R.; Shinn, P.; Pellegrini, M.; Jacobsen, S.E.; et al. Genome-wide High-Resolution Mapping and Functional Analysis of DNA Methylation in Arabidopsis. Cell 2006, 126, 1189-1201. [CrossRef]

73. Richards, C.L.; Alonso, C.; Becker, C.; Bossdorf, O.; Bucher, E.; Colome-Tatche, M.; Durka, W.; Engelhardt, J.; Gáspár, B.; Gogol-Döring, A.; et al. Ecological plant epigenetics: Evidence from model and non-model species, and the way forward. Ecol. Lett. 2017, 20, 1576-1590. [CrossRef]

74. Baulcombe, D.C.; Dean, C. Epigenetic Regulation in Plant Responses to the Environment. Cold Spring Harb. Perspect. Biol. 2014, 6, a019471. [CrossRef]

75. Hébrard, C.; Peterson, D.G.; Willems, G.; Delaunay, A.; Jesson, B.; Lefebvre, M.; Barnes, S.; Maury, S. Epigenomics and bolting tolerance in sugar beet genotypes. J. Exp. Bot. 2015, 67, 207-225. [CrossRef] [PubMed]

76. He, Y.; Li, Z. Epigenetic Environmental Memories in Plants: Establishment, Maintenance, and Reprogramming. Trends Genet. 2018, 34, 856-866. [CrossRef]

77. Cubas, P.; Vincent, C.; Coen, E. An epigenetic mutation responsible for natural variation in floral symmetry. Nature 1999, 401, 157-161. [CrossRef] [PubMed] 
78. Manning, K.; Tör, M.; Poole, M.; Hong, Y.; Thompson, A.J.; King, G.J.; Giovannoni, J.J.; Seymour, G.B. A naturally occurring epigenetic mutation in a gene encoding an SBP-box transcription factor inhibits tomato fruit ripening. Nat. Genet. 2006, 38, 948-952. [CrossRef]

79. Miura, K.; Okada, Y.; Aoi, T.; Okada, A.; Takahashi, K.; Okita, K.; Nakagawa, M.; Koyanagi, M.; Tanabe, K.; Ohnuki, M.; et al. Variation in the safety of induced pluripotent stem cell lines. Nat. Biotechnol. 2009, 27, 743-745. [CrossRef]

80. Lisch, D. How important are transposons for plant evolution? Nat. Rev. Genet. 2012, 14, 49-61. [CrossRef]

81. Johannes, F.; Porcher, E.; Teixeira, F.K.; Saliba-Colombani, V.; Simon, M.; Agier, N.; Bulski, A.; Albuisson, J.; Heredia, F.; Audigier, P.; et al. Assessing the Impact of Transgenerational Epigenetic Variation on Complex Traits. PLoS Genet. 2009, 5, e1000530. [CrossRef]

82. Reinders, J.; Wulff, B.B.; Mirouze, M.; Marí-Ordóñez, A.; Dapp, M.; Rozhon, W.; Bucher, E.; Theiler, G.; Paszkowski, J. Compromised stability of DNA methylation and transposon immobilization in mosaic Arabidopsis epigenomes. Genes Dev. 2009, 23, 939-950. [CrossRef]

83. Colome-Tatche, M.; Cortijo, S.; Wardenaar, R.; Morgado, L.; Lahouze, B.; Sarazin, A.; Etcheverry, M.; Martin, A.; Feng, S.; Duvernois-Berthet, E.; et al. Features of the Arabidopsis recombination landscape resulting from the combined loss of sequence variation and DNA methylation. Proc. Natl. Acad. Sci. USA 2012, 109, 16240-16245. [CrossRef]

84. Roux, F.; Colome-Tatche, M.; Edelist, C.; Wardenaar, R.; Guerche, P.; Hospital, F.; Colot, V.; Jansen, R.C.; Johannes, F. Genome-Wide Epigenetic Perturbation Jump-Starts Patterns of Heritable Variation Found in Nature. Genetics 2011, 188, 1015-1017. [CrossRef]

85. Latzel, V.; Zhang, Y.; Moritz, K.K.; Fischer, M.; Bossdorf, O. Epigenetic variation in plant responses to defence hormones. Ann. Bot. 2012, 110, 1423-1428. [CrossRef]

86. Zhang, Y.Y.; Fischer, M.; Colot, V.; Bossdorf, O. Epigenetic variation creates potential for evolution of plant phenotypic plasticity. New Phytol. 2012, 197, 314-322. [CrossRef]

87. Kooke, R.; Johannes, F.; Wardenaar, R.; Becker, F.; Etcheverry, M.; Colot, V.; Vreugdenhil, D.; Keurentjes, J.J. Epigenetic Basis of Morphological Variation and Phenotypic Plasticity in Arabidopsis thaliana. Plant Cell 2015, 27, 337-348. [CrossRef]

88. Gallusci, P.; Dai, Z.; Génard, M.; Gauffretau, A.; Leblanc-Fournier, N.; Richard-Molard, C.; Vile, D.; Brunel-Muguet, S. Epigenetics for Plant Improvement: Current Knowledge and Modeling Avenues. Trends Plant Sci. 2017, 22, 610-623. [CrossRef]

89. Springer, N.M.; Schmitz, R.J. Exploiting induced and natural epigenetic variation for crop improvement. Nat. Rev. Genet. 2017, 18, 563-575. [CrossRef]

90. Skinner, M.K. Environmental Epigenetics and a Unified Theory of the Molecular Aspects of Evolution: A Neo-Lamarckian Concept that Facilitates Neo-Darwinian Evolution. Genome Biol. Evol. 2015, 7, 1296-1302. [CrossRef]

91. Kawakatsu, T.; Huang, S.-S.C.; Jupe, F.; Sasaki, E.; Schmitz, R.J.; Urich, M.A.; Castanon, R.; Nery, J.R.; Barragan, C.; He, Y.; et al. Epigenomic diversity in a global collection of Arabidopsis thaliana accessions. Cell 2016, 166, 492-505. [CrossRef]

92. Schmid, K.J.; Heichinger, C.; Schmid, D.C.; Guthörl, D.; Gagliardini, V.; Bruggmann, R.; Aluri, S.; Aquino, C.; Schmid, B.; Turnbull, L.A.; et al. Contribution of epigenetic variation to adaptation in Arabidopsis. Nat. Commun. 2018, 9, 4446. [CrossRef]

93. Thiebaut, F.; Hemerly, A.S.; Ferreira, P.C.G. A Role for Epigenetic Regulation in the Adaptation and Stress Responses of Non-model Plants. Front. Plant Sci. 2019, 10, 246. [CrossRef]

94. Chang, Y.N.; Zhu, C.; Jiang, J.; Zhang, H.; Zhu, J.K.; Duan, C.G. Epigenetic regulation in plant abiotic stress responses. J. Integr. Plant Biol. 2020, 62, 563-580. [CrossRef]

95. Alonso, C.; Ramos-Cruz, D.; Becker, C. The role of plant epigenetics in biotic interactions. New Phytol. 2018, 221, 731-737. [CrossRef]

96. Yamamuro, C.; Zhu, J.K.; Yang, Z. Epigenetic Modifications and Plant Hormone Action. Mol. Plant 2015, 9, 57-70. [CrossRef]

97. Ojolo, S.P.; Cao, S.; Priyadarshani, S.V.G.N.; Li, W.; Yan, M.; Aslam, M.; Zhao, H.; Qin, Y. Regulation of Plant Growth and Development: A Review from a Chromatin Remodeling Perspective. Front. Plant Sci. 2018, 9, 9. [CrossRef] 
98. Maury, S.; Sow, M.D.; Le Gac, A.-L.; Genitoni, J.; Placette, C.L.; Mozgova, I. Phytohormone and Chromatin Crosstalk: The Missing Link for Developmental Plasticity? Front. Plant Sci. 2019, 10, 395. [CrossRef]

99. Tuskan, G.A.; DiFazio, S.; Jansson, S.; Bohlmann, J.; Grigoriev, I.; Hellsten, U.; Putnam, N.H.; Ralph, S.; Rombauts, S.; Salamov, A.; et al. The Genome of Black Cottonwood, Populus trichocarpa (Torr. \& Gray). Science 2006, 313, 1596-1604. [CrossRef]

100. Nystedt, B.; Street, N.R.; Wetterbom, A.; Zuccolo, A.; Lin, Y.-C.; Scofield, D.; Vezzi, F.; Delhomme, N.; Giacomello, S.; Alexeyenko, A.; et al. The Norway spruce genome sequence and conifer genome evolution. Nature 2013, 497, 579-584. [CrossRef]

101. Myburg, A.A.; Grattapaglia, D.; Tuskan, G.A.; Hellsten, U.; Hayes, R.D.; Grimwood, J.; Jenkins, J.; Lindquist, E.; Tice, H.; Bauer, D.; et al. The genome of Eucalyptus grandis. Nature 2014, 510, 356-362. [CrossRef]

102. Crisp, P.A.; Ganguly, D.R.; Eichten, S.R.; Borevitz, J.; Pogson, B. Reconsidering plant memory: Intersections between stress recovery, RNA turnover, and epigenetics. Sci. Adv. 2016, 2, e1501340. [CrossRef]

103. Lämke, J.; Bäurle, I. Epigenetic and chromatin-based mechanisms in environmental stress adaptation and stress memory in plants. Genome Biol. 2017, 18, 124. [CrossRef]

104. Bäurle, I.; Trindade, I. Chromatin regulation of somatic abiotic stress memory. J. Exp. Bot. 2020, 71, 5269-5279. [CrossRef]

105. Ma, X.J.; Zhang, C.; Zhang, B.; Yang, C.; Li, S. Identification of genes regulated by histone acetylation during root development in Populus trichocarpa. BMC Genom. 2016, 17, 96. [CrossRef]

106. Li, Y.; Dong, X.M.; Jin, F.; Shen, Z.; Chao, Q.; Wang, B.C. Histone Acetylation Modifications Affect Tissue-Dependent Expression of Poplar Homologs of C4 Photosynthetic Enzyme Genes. Front. Plant Sci. 2017, 8, 13. [CrossRef]

107. Klimaszewska, K.; Noceda, C.; Pelletier, G.; Label, P.; Rodriguez, R.; Lelu-Walter, M.A. Biological characterization of young and aged embryogenic cultures of Pinus pinaster (Ait.). Vitr. Cell. Dev. Biol. Anim. 2008, 45, 20-33. [CrossRef]

108. Rico, L.; Ogaya, R.; Barbeta, A.; Peñuelas, J. Changes in DNA methylation fingerprint of Quercus ilex trees in response to experimental field drought simulating projected climate change. Plant Biol. 2013, 16, 419-427. [CrossRef]

109. Yakovlev, I.A.; Fossdal, C.G.; Skrøppa, T.; Olsen, J.E.; Jahren, A.H.; Johnsen, Ø. An adaptive epigenetic memory in conifers with important implications for seed production. Seed Sci. Res. 2012, 22, 63-76. [CrossRef]

110. Yakovlev, I.A.; Lee, Y.; Rotter, B.; Olsen, J.E.; Skrøppa, T.; Johnsen, Ø.; Fossdal, C.G. Temperature-dependent differential transcriptomes during formation of an epigenetic memory in Norway spruce embryogenesis. Tree Genet. Genomes 2014, 10, 355-366. [CrossRef]

111. Yakovlev, I.A.; Carneros, E.; Lee, Y.; Olsen, J.E.; Fossdal, C.G. Transcriptional profiling of epigenetic regulators in somatic embryos during temperature induced formation of an epigenetic memory in Norway spruce. Planta 2016, 243, 1237-1249. [CrossRef]

112. Schönberger, B.; Chen, X.; Mager, S.; Ludewig, U. Site-Dependent Differences in DNA Methylation and Their Impact on Plant Establishment and Phosphorus Nutrition in Populus trichocarpa. PLoS ONE 2016, 11, e0168623. [CrossRef]

113. D’Urso, A.; Brickner, J.H. Epigenetic transcriptional memory. Curr. Genet. 2016, 63, 435-439. [CrossRef]

114. Avramova, Z. Defence-related priming and responses to recurring drought: Two manifestations of plant transcriptional memory mediated by the ABA and JA signalling pathways. Plant Cell Environ. 2018, 42, 983-997. [CrossRef]

115. Hilker, M.; Schmülling, T. Stress priming, memory, and signalling in plants. Plant Cell Environ. 2019, 42, 753-761. [CrossRef] [PubMed]

116. Sollars, E.S.A.; Buggs, R.J.A. Genome-wide epigenetic variation among ash trees differing in susceptibility to a fungal disease. BMC Genom. 2018, 19, 502. [CrossRef] [PubMed]

117. Yan, L.; Fan, G.; Li, X. Genome-wide analysis of three histone marks and gene expression in Paulownia fortunei with phytoplasma infection. BMC Genom. 2019, 20, 234. [CrossRef] [PubMed]

118. Gourcilleau, D.; Bogeat-Triboulot, M.B.; Le Thiec, D.; Placette, C.L.; Delaunay, A.; Abuelsoud, W.; Brignolas, F.; Maury, S. DNA methylation and histone acetylation: Genotypic variations in hybrid poplars, impact of water deficit and relationships with productivity. Ann. For. Sci. 2010, 67, 208. [CrossRef] 
119. Raj, S.; Bräutigam, K.; Hamanishi, E.T.; Wilkins, O.; Thomas, B.R.; Schroeder, W.; Mansfield, S.D.; Plant, A.L.; Campbell, M.M. Clone history shapes Populus drought responses. Proc. Natl. Acad. Sci. USA 2011, 108, 12521-12526. [CrossRef]

120. Neves, D.M.; Almeida, L.A.D.H.; Santana-Vieira, D.D.S.; Freschi, L.; Ferreira, C.F.; Filho, W.D.S.S.; Costa, M.G.C.; Micheli, F.; Filho, M.A.C.; Gesteira, A.D.S. Recurrent water deficit causes epigenetic and hormonal changes in citrus plants. Sci. Rep. 2017, 7, 13684. [CrossRef]

121. Correia, B.; Valledor, L.; Hancock, R.D.; Jesus, C.; Amaral, J.; Meijon, M.; Pinto, G. Depicting how Eucalyptus globulus survives drought: Involvement of redox and DNA methylation events. Funct. Plant Biol. 2016, 43, 838. [CrossRef]

122. Plitta-Michalak, B.P.; Naskręt-Barciszewska, M.Z.; Kotlarski, S.; Tomaszewski, D.; Tylkowski, T.; Barciszewski, J.; Chmielarz, P.; Michalak, M. Changes in genomic 5-methylcytosine level mirror the response of orthodox (Acer platanoides L.) and recalcitrant (Acer pseudoplatanus L.) seeds to severe desiccation. Tree Physiol. 2017, 38, 617-629. [CrossRef]

123. Placette, C.L.; Le Gac, A.L.; Chauveau, D.; Segura, V.; Delaunay, A.; Lesage-Descauses, M.C.; Hummel, I.; Cohen, D.; Jesson, B.; Le Thiec, D.; et al. Changes in the epigenome and transcriptome of the poplar shoot apical meristem in response to water availability affect preferentially hormone pathways. J. Exp. Bot. 2017, 69, 537-551. [CrossRef]

124. Le Gac, A.L.; Placette, C.L.; Chauveau, D.; Segura, V.; Delaunay, A.; Fichot, R.; Marron, N.; Le Jan, I.; Berthelot, A.; Bodineau, G.; et al. Winter-dormant shoot apical meristem in poplar trees shows environmental epigenetic memory. J. Exp. Bot. 2018, 69, 4821-4837. [CrossRef]

125. Sow, M.D.; Segura, V.; Chamaillard, S.; Jorge, V.; Delaunay, A.; Placette, C.L.; Fichot, R.; Faivre-Rampant, P.; Villar, M.; Brignolas, F.; et al. Narrow-sense heritability and PST estimates of DNA methylation in three Populus nigra L. populations under contrasting water availability. Tree Genet. Genomes 2018, 14, 78. [CrossRef]

126. Le Gac, A.L.; Lafon-Placette, C.; Delaunay, A.; Maury, S. Developmental, Genetic and Environmental Variations of Global DNA Methylation in the First Leaves Emerging from the Shoot Apical Meristem in Poplar Trees. Plant Signal. Behav. 2019, 14, e1596717. [CrossRef]

127. Liu, J.G.; Han, X.; Yang, T.; Cui, W.H.; Wu, A.M.; Fu, C.; Wang, B.C.; Liu, L. Genome-wide transcriptional adaptation to salt stress in Populus. BMC Plant Biol. 2019, 19, 367. [CrossRef] [PubMed]

128. Liu, C.; Li, H.; Lin, J.; Wang, Y.; Xu, X.; Cheng, Z.M.; Chang, Y. Genome-Wide Characterization of DNA Demethylase Genes and Their Association with Salt Response in Pyrus. Genes 2018, 9, 398. [CrossRef] [PubMed]

129. Murata, N.; Iwanaga, F.; Maimaiti, A.; Imada, S.; Mori, N.; Tanaka, K.; Yamanaka, N. Significant improvement of salt tolerance with 2-day acclimatization treatment in Elaeagnus oxycarpa seedlings. Environ. Exp. Bot. 2012, 77, 170-174. [CrossRef]

130. Cicatelli, A.; Todeschini, V.; Lingua, G.; Biondi, S.; Torrigiani, P.; Castiglione, S. Epigenetic control of heavy metal stress response in mycorrhizal versus non-mycorrhizal poplar plants. Environ. Sci. Pollut. Res. 2013, 21, 1723-1737. [CrossRef]

131. Carón, M.M.; De Frenne, P.; Brunet, J.; Chabrerie, O.; Cousins, S.A.O.; De Backer, L.; Decocq, G.; Diekmann, M.; Heinken, T.; Kolb, A.; et al. Interacting effects of warming and drought on regeneration and early growth of Acer pseudoplatanus and A. platanoides. Plant Biol. 2014, 17, 52-62. [CrossRef]

132. Conde, D.; Le Gac, A.-L.; Perales, M.; Dervinis, C.; Kirst, M.; Maury, S.; González-Melendi, P.; Allona, I. Chilling-responsive DEMETER-LIKE DNA demethylase mediates in poplar bud break. Plant Cell Environ. 2017, 40, 2236-2249. [CrossRef]

133. Conde, D.; Moreno-Cortés, A.; Dervinis, C.; Ramos-Sánchez, J.M.; Kirst, M.; Perales, M.; González-Melendi, P.; Allona, I. Overexpression of DEMETER, a DNA demethylase, promotes early apical bud maturation in poplar. Plant Cell Environ. 2017, 40, 2806-2819. [CrossRef]

134. Deng, X.; Wang, J.; Li, Y.; Wu, S.; Yang, S.; Chao, J.; Chen, Y.; Zhang, S.; Shi, M.; Tian, W.M. Comparative transcriptome analysis reveals phytohormone signalings, heat shock module and ROS scavenger mediate the cold-tolerance of rubber tree. Sci. Rep. 2018, 8, 4931. [CrossRef]

135. Dewan, S.; Mijnsbrugge, K.V.; De Frenne, P.; Steenackers, M.; Michiels, B.; Verheyen, K. Maternal temperature during seed maturation affects seed germination and timing of bud set in seedlings of European black poplar. For. Ecol. Manag. 2018, 410, 126-135. [CrossRef] 
136. Yakovlev, I.A.; Asante, D.K.; Fossdal, C.G.; Junttila, O.; Johnsen, O. Differential gene expression related to an epigenetic memory affecting climatic adaptation in Norway spruce. Plant Sci. 2011, 180, 132-139. [CrossRef] [PubMed]

137. Fox, H.; Doron-Faigenboim, A.; Kelly, G.; Bourstein, R.; Attia, Z.; Zhou, J.; Moshe, Y.; Moshelion, M.; David-Schwartz, R. Transcriptome analysis of Pinus halepensis under drought stress and during recovery. Tree Physiol. 2017, 38, 423-441. [CrossRef]

138. Li, S.; Lin, Y.-C.; Wang, P.; Zhang, B.; Li, M.; Chen, S.; Shi, R.; Tunlaya-Anukit, S.; Liu, X.; Wang, Z.; et al. The AREB1 Transcription Factor Influences Histone Acetylation to Regulate Drought Responses and Tolerance in Populus trichocarpa. Plant Cell 2018, 31, 663-686. [CrossRef] [PubMed]

139. Duarte, G.T.; Volkova, P.Y.; Geras'Kin, S.A. The response profile to chronic radiation exposure based on the transcriptome analysis of Scots pine from Chernobyl affected zone. Environ. Pollut. 2019, 250, 618-626. [CrossRef] [PubMed]

140. Lira, C.F.; Parisod, C.; Fernandes, R.A.; Mata, C.S.; Cardoso, M.A.; Ferreira, P.C.G. Epigenetic Variation in Mangrove Plants Occurring in Contrasting Natural Environment. PLoS ONE 2010, 5, e10326. [CrossRef]

141. Valledor, L.; Cañal, M.-J.; Pascual, J.; Rodríguez, R.; Meijon, M. Early induced protein 1 (PrELIP1) and other photosynthetic, stress and epigenetic regulation genes are involved in Pinus radiata D. don UV-B radiation response. Physiol. Plant. 2012, 146, 308-320. [CrossRef]

142. Johnsen, O.; Daehlen, O.G.; Østreng, G.; Skrøppa, T.; Dæhlen, O.G. Daylength and temperature during seed production interactively affect adaptive performance of Picea abies progenies. New Phytol. 2005, 168, 589-596. [CrossRef]

143. Kvaalen, H.; Øystein, J. Timing of bud set in Picea abies is regulated by a memory of temperature during zygotic and somatic embryogenesis. New Phytol. 2007, 177, 49-59. [CrossRef]

144. Carneros, E.; Yakovlev, I.; Viejo, M.; Olsen, J.E.; Fossdal, C.G. The epigenetic memory of temperature during embryogenesis modifies the expression of bud burst-related genes in Norway spruce epitypes. Planta 2017, 246, 553-566. [CrossRef]

145. Besnard, G.; Acheré, V.; Jeandroz, S.; Johnsen, Ø.; Rampant, P.F.; Baumann, R.; Müller-Starck, G.; Skrøppa, T.; Favre, J.M. Does maternal environmental condition during reproductive development induce genotypic selection in Picea abies? Ann. For. Sci. 2008, 65, 109. [CrossRef]

146. Skrøppa, T.; Tollefsrud, M.M.; Sperisen, C.; Johnsen, Ø. Rapid change in adaptive performance from one generation to the next in Picea abies-Central European trees in a Nordic environment. Tree Genet. Genomes 2009, 6, 93-99. [CrossRef]

147. Yakovlev, I.A.; Fossdal, C.G.; Johnsen, O. MicroRNAs, the epigenetic memory and climatic adaptation in Norway spruce. New Phytol. 2010, 187, 1154-1169. [CrossRef] [PubMed]

148. Yakovlev, I.A.; Fossdal, C.G. In Silico Analysis of Small RNAs Suggest Roles for Novel and Conserved miRNAs in the Formation of Epigenetic Memory in Somatic Embryos of Norway Spruce. Front. Physiol. 2017, 8, 102-118. [CrossRef]

149. Camisón, Á.; Martín, M.Á.; Oliva, J.; Elfstrand, M.; Solla, A. Increased tolerance to Phytophthora cinnamomi in offspring of ink-diseased chestnut (Castanea sativa Miller) trees. Ann. For. Sci. 2019, 76, 119. [CrossRef]

150. Vivas, M.; Zas, R.; Sampedro, L.; Solla, A. Environmental Maternal Effects Mediate the Resistance of Maritime Pine to Biotic Stress. PLoS ONE 2013, 8, e70148. [CrossRef]

151. Lamelas, L.; Valledor, L.; Escandón, M.; Pinto, G.; Cañal, M.J.; Meijon, M. Integrative analysis of the nuclear proteome in Pinus radiata reveals thermopriming coupled to epigenetic regulation. J. Exp. Bot. 2019, 71, 2040-2057. [CrossRef]

152. Mageroy, M.H.; Christiansen, E.; Långström, B.; Borg-Karlson, A.; Solheim, H.; Björklund, N.; Zhao, T.; Schmidt, A.; Fossdal, C.G.; Krokene, P. Priming of inducible defenses protects Norway spruce against tree-killing bark beetles. Plant Cell Environ. 2019, 43, 420-430. [CrossRef]

153. Wilkinson, S.W.; Magerøy, M.H.; Sánchez, A.L.; Smith, L.M.; Furci, L.; Cotton, T.A.; Krokene, P.; Ton, J. Surviving in a Hostile World: Plant Strategies to Resist Pests and Diseases. Annu. Rev. Phytopathol. 2019, 57, 505-529. [CrossRef]

154. Pigliucci, M. Developmental phenotypic plasticity: Where internal programming meets the external environment. Curr. Opin. Plant Biol. 1998, 1, 87-91. [CrossRef] 
155. Gaillochet, C.; Lohmann, J.U. The never-ending story: From pluripotency to plant developmental plasticity. Development 2015, 142, 2237-2249. [CrossRef] [PubMed]

156. Achour, Z.; Archipiano, M.; Barneche, F.; Baurens, C.; Beckert, M.; Ben, C.; Epigenetics in Plant Breeding. Article de Positionnement du GROUPEMENT D'intérêt Scientifique Biotechnologies Vertes et de L'alliance Nationale de Recherche Pour L'environnement. 2017. Available online: http:/www.gisbiotechnologiesvertes. $\mathrm{com} / \mathrm{fr} /$ publications/position-paperepigenetics-in-plant-breeding (accessed on 13 February 2017).

157. Gallusci, P.; Bucher, E.; Mirouze, M. Preface. In Advances in Botanical Research; Mirouze, M., Bucher, E., Gallusci, P., Eds.; Plant Epigenetics Coming of Age for Breeding Applications; Academic Press: Cambridge, MA, USA, 2018; Volume 88, pp. 15-18. [CrossRef]

158. Ryder, P.; McKeown, P.C.; Fort, A.; Spillane, C. Epigenetics and Heterosis in Crop Plants. In Epigenetics in Plants of Agronomic Importance: Fundamentals and Applications; Alvarez-Venegas, R., De-la-Peña, C., Casas-Mollano, J.A., Eds.; Springer International Publishing: Cham, Switzerland, 2019; pp. 129-147. [CrossRef]

159. Yugi, K.; Kubota, H.; Hatano, A.; Kuroda, S. Trans-Omics: How to Reconstruct Biochemical Networks Across Multiple 'Omic' Layers. Trends Biotechnol. 2016, 34, 276-290. [CrossRef] [PubMed]

160. Bewg, W.P.; Ci, D.; Tsai, C.-J. Genome Editing in Trees: From Multiple Repair Pathways to Long-Term Stability. Front. Plant Sci. 2018, 9, 9. [CrossRef] [PubMed]

161. Gao, M.; Huang, Q.; Chu, Y.; Ding, C.; Zhang, B.; Su, X. Analysis of the leaf methylomes of parents and their hybrids provides new insight into hybrid vigor in Populus deltoides. BMC Genetics 2014, 15, S8. [CrossRef] [PubMed]

162. Weiberg, A.; Bellinger, M.; Jin, H. Conversations between kingdoms: Small RNAs. Curr. Opin. Biotechnol. 2015, 32, 207-215. [CrossRef] [PubMed]

163. Cai, Q.; He, B.; Kogel, K.H.; Jin, H. Cross-kingdom RNA trafficking and environmental RNAi-Nature's blueprint for modern crop protection strategies. Curr. Opin. Microbiol. 2018, 46, 58-64. [CrossRef]

164. Muhammad, T.; Zhang, F.; Zhang, Y.; Liang, Y. RNA Interference: A Natural Immune System of Plants to Counteract Biotic Stressors. Cells 2019, 8, 38. [CrossRef]

165. Ramirez-Prado, J.S.; Abulfaraj, A.A.; Rayapuram, N.; Benhamed, M.; Hirt, H. Plant Immunity: From Signaling to Epigenetic Control of Defense. Trends Plant Sci. 2018, 23, 833-844. [CrossRef]

166. Peng, H.; Zhang, J. Plant genomic DNA methylation in response to stresses: Potential applications and challenges in plant breeding. Prog. Nat. Sci. 2009, 19, 1037-1045. [CrossRef]

167. Ci, D.; Song, Y.; Tian, M.; Zhang, D. Methylation of miRNA genes in the response to temperature stress in Populus simonii. Front. Plant Sci. 2015, 6, 921. [CrossRef]

168. Ma, K.; Song, Y.; Jiang, X.; Zhang, Z.; Li, B.; Zhang, D. Photosynthetic response to genome methylation affects the growth of Chinese white poplar. Tree Genet. Genomes 2012, 8, 1407-1421. [CrossRef]

169. Baison, J.; Vidalis, A.; Zhou, L.; Chen, Z.; Li, Z.; Sillanpää, M.J.; Bernhardsson, C.; Scofield, D.; Forsberg, N.; Grahn, T.; et al. Genome-wide association study identified novel candidate loci affecting wood formation in Norway spruce. Plant J. 2019, 100, 83-100. [CrossRef]

170. Champigny, M.J.; Unda, F.; Skyba, O.; Soolanayakanahally, R.Y.; Mansfield, S.D.; Campbell, M.M. Learning from methylomes: Epigenomic correlates of Populus balsamifera traits based on deep learning models of natural DNA methylation. Plant Biotechnol. J. 2019, 18, 1361-1375. [CrossRef] [PubMed]

171. Taagen, E.; Bogdanove, A.J.; Sorrells, M.E. Counting on Crossovers: Controlled Recombination for Plant Breeding. Trends Plant Sci. 2020, 25, 455-465. [CrossRef] [PubMed]

172. Jubierre, L.; Jiménez, C.; Rovira, E.; Soriano, A.; Sábado, C.; Gros, L.; Llort, A.; Hladun, R.; Roma, J.; De Toledo, J.S.; et al. Targeting of epigenetic regulators in neuroblastoma. Exp. Mol. Med. 2018, 50, 51. [CrossRef]

173. Richards, E.J. Population epigenetics. Curr. Opin. Genet. Dev. 2008, 18, 221-226. [CrossRef]

174. Greally, J.M. Population epigenetics. Curr. Opin. Syst. Biol. 2017, 1, 84-89. [CrossRef]

175. Tasaki, S.; Suzuki, K.; Kassai, Y.; Takeshita, M.; Murota, A.; Kondo, Y.; Ando, T.; Nakayama, Y.; Okuzono, Y.; Takiguchi, M.; et al. Multi-omics monitoring of drug response in rheumatoid arthritis in pursuit of molecular remission. Nat. Commun. 2018, 9, 2755. [CrossRef] [PubMed]

176. Neale, D.B.; Kremer, A. Forest tree genomics: Growing resources and applications. Nat. Rev. Genet. 2011, 12, 111-122. [CrossRef] [PubMed] 
177. Balao, F.; Paun, O.; Alonso, C. Uncovering the contribution of epigenetics to plant phenotypic variation in Mediterranean ecosystems. Plant Biol. 2017, 20, 38-49. [CrossRef] [PubMed]

178. Neale, D.B.; Langley, C.H.; Salzberg, S.L.; Wegrzyn, J. Open access to tree genomes: The path to a better forest. Genome Biol. 2013, 14, 120. [CrossRef] [PubMed]

(C) 2020 by the authors. Licensee MDPI, Basel, Switzerland. This article is an open access article distributed under the terms and conditions of the Creative Commons Attribution (CC BY) license (http://creativecommons.org/licenses/by/4.0/). 